\title{
Nontraditional, interdisciplinary immersive approach to Chemical Engineer- ing design: A case study assessment and analysis
}

\section{Dr. Rebecca Jo Pinkelman, Technische Universität Darmstadt}

Rebecca J. Pinkelman graduated from Chadron State College with a B.S. in Chemistry and Biology in 2008. She received her M.S. and Ph.D. in Chemical Engineering from South Dakota School of Mines and Technology in 2010 and 2014, respectively. She is currently a post-doctoral research scientist in the Mechanical and Process Engineering Department at the Technische Universität Darmstadt.

\section{Dr. David J. Dixon, South Dakota School of Mines and Technology}

Dr. Dixon currently serves as a Professor of Chemical Engineering in the Chemical and Biological Engineering Department at the South Dakota School of Mines and Technology, in Rapid City, South Dakota (USA). He was a Fulbright Scholar at the Technical University Darmstadt in Darmstadt, Germany during the 2009-2010 year. He is a member of ASEE and AICHE and has an active interest in improving engineering education and promoting study abroad opportunities.

\section{Prof. Manfred J Hampe, Technische Universität Darmstadt}

Manfred J. Hampe graduated from Technische Universität Clausthal in 1976 and received his doctorate in engineering from Technische Universität München in 1980. He worked as a process engineer in the central research division of Bayer AG in Leverkusen before he became full professor of Thermal Process Engineering in the Department of Mechanical Engineering at Technische Universität Darmstadt in 1995. His research interests are in the field of transport phenomena at fluid interfaces. He has been the chairman of the Working Party on Education in Chemical and Process Engineering of the VDI-Society for Chemical and Process Engineering and member of the European Working Party on Education in Chemical Engineering for many years. He is the vice-chairman of the council of the faculties of mechanical and process engineering in Germany and chairman of 4ING, the German Council of University Faculties in Engineering and Informatics. Between 2004 and 2013 he was one of the 19 German Bologna experts. He received the ars legendi award 2013 of the Stifterverband and the German Rectors Conference. 


\title{
Nontraditional, interdisciplinary immersive approach to Chemical Engineering design: A case study assessment and analysis
}

\begin{abstract}
In our increasingly globalized world and project based, interdisciplinary industrial teams, there is a need for concurrent teaching and learning of design skills and professional skills, e.g., teamwork, global competence (awareness), etc. This paper describes, assesses, and analyzes a non-traditional, immersive approach to teaching a capstone chemical engineering process design course. The Advanced Design Project (ADP) course is a three-week, intensive senior level design course, which includes mechanical engineers and chemists from a technical German university and chemical engineers from a private German university of applied science and an American university. The nontraditional approach utilized in the ADP course meets the ABET accreditation standards set by the traditional American chemical engineering capstone process design course. Additional emphasis, especially in terms of acquisition of communication skills, ability to work on a multidisciplinary team, and obtain a global perspective, is obtained in the ADP course. These skills are typically much more difficult to practice in a traditional American senior design course.

Through the ADP course, students perceived that they had increased their knowledge and skills in design and teamwork. Open questions about the concepts of design and teamwork were analyzed quantitatively with a rubric and qualitatively to look at student perceptions. According to the scored assessment, students had lower competences in design and teamwork in comparison to their self-assessment. The qualitative assessment showed that students understand parts of design and teamwork, but were unable to put together a full, more nuanced concept of design and teamwork. This non-traditional, intercultural, interdisciplinary approach to chemical engineering process engineering design exposes students to broader perspectives and a more "real-life" industry situation, thus better preparing chemical engineering students for their future professional lives.
\end{abstract}

\section{Introduction}

As project work and globalization are becoming more prevalent in the workplace, there is an increasing need for graduating engineers to have additional proficiencies such as global competence, teamwork, and communication skills alongside core engineering skills and knowledge. According to Warnick (2011), surveyed multinational companies indicated that the ability to communicate cross-culturally is an important part of global competence ${ }^{1}$. Students need to be able to work and communicate well with professionals from other disciplines and cultures to develop well-rounded, unique solutions to problems. Professional competence has been previously defined as a high level of motivation, use of intelligence to solve problems and make decisions, teamwork, management and leadership of others, communication, planning and management of a project and resources, innovation, and a strategic view of the larger picture of the project ${ }^{2,3}$. These competences, along with strong technical knowledge skill set, have been linked to future professional engineering success ${ }^{3,4}$. Additionally, ABET requires that graduating engineers meet the following select criteria: (d) ability to function on multidisciplinary teams; (f) understanding of professional and ethical responsibility; (g) ability to communicate effectively; and (h) the broad education necessary to understand the impact of engineering solutions in a global and societal context ${ }^{5}$. 
It has been suggested that problem-based learning and project-oriented learning, which includes capstone design courses, are effective means to achieve these requirements including the ABET criteria $^{6-9}$. Mills and Treagust (2003) summarized their observations on the differences between problem-based learning and project-oriented learning as project-oriented learning is more application and professional work based. Thus, it is over a longer time period than problem-based learning. Project-oriented courses also include time and resource management, task and role differentiation, and more self-motivation and direction in comparison to problem-based learning. Problem-based learning tends to focus more on knowledge acquisition ${ }^{9}$. It has been shown that project-oriented courses increase retention rates ${ }^{10-12}$, intellectual development ${ }^{13}$, and increase not only students' technical and design knowledge, but also their technical writing and research skills ${ }^{14}$. In addition, project-oriented courses expose students to the broader context of engineering design, and students learn best when experiencing the entirety of the content area through real-life examples and working with and learning from their peers ${ }^{6,15-17}$.

Project-oriented learning and capstone design courses allow for the concurrent teaching of design through application and teamwork skills, which are needed for future professional success $3,4,18,19$. This teaches students the "messiness" of real-life industrial and team problems and has been shown to have short and long-term positive impact on teamwork skills ${ }^{18-20}$.

An effective method to teach project-oriented learning and capstone design courses is through an intensive, immersive approach. The project and content are equivalent to a semester long (traditional) course but in a compressed time format from days to a few weeks ${ }^{21,22}$. It has been previously found that students had greater academic success in a three-week intensive course compared to the traditional format due to decreased course fragmentation, increased studentteacher interaction, increased student camaraderie, greater student satisfaction, and increased focus, i.e., fewer distractions ${ }^{21}$. Intensive courses tend to be more focused on acquisition and application of skills and not learning new concepts, ${ }^{22}$ which aligns with, and complements, projectorientated learning.

\section{Objectives}

This paper outlines, evaluates, and assesses a non-traditional method to teaching chemical engineering process design utilizing an intensive, immersive approach with interdisciplinary and intercultural aspects. The Advanced Design Project course is compared to an ABET certified program in the United States to show that this non-traditional approach meets and exceeds the more traditional semester long capstone design course, with respect to meeting ABET accreditation standards. The main objectives of the developed assessment are to show how students achieved the desired outcomes of increasing knowledge and skills in design and teamwork, to discover the important aspects of and connections between design and teamwork from students, and to compare student's perceptions of design and teamwork to measured competence.

\section{Course description}

The Advanced Design Project (ADP) course is a three-week, intensive, immersive design project class that is interdisciplinary and intercultural with two main learning objectives: the development of professional skills through teamwork; and the enhancement of design skills through application. It is a bridge between a typical design project course and a real industrial design project. The topic (a chemical plant) is developed with and supported by an industrial partner using their actual plant 
data and parameters. The interdisciplinary and intercultural team is more representative of industrial design teams, particularly from global companies.

Due to the nature and scope required to design an entire chemical process in an intensive threeweek period, this course is taught as a more structured design with some room for variation and creativity in the plant design. The entire design is broken into major tasks, e.g., mass balance, kinetics and reactor design, separation, safety, and economics. The tutors develop specific tasks and goals (daily and overall) corresponding to these major tasks that the teams must meet. Additionally, during the second week, certain teams may be asked for more advanced designs, for example, incorporating heat integration, varying process variables for increased production, etc. During the first two weeks, the students attend short lectures (approximately one hour in the mornings) introducing the major tasks, but the majority of class time was used for team design work. Since there are only approximately five tutors for 60-70 students, broken into 10-12 teams, students are highly encouraged to collaborate among each other, especially for troubleshooting. During the third week, students polish their final design, prepare for their final design presentations at the industrial partner, and finish their team's formal technical report.

\section{Methods}

Composition and project design of ADP 2016

Sixty-nine students from three universities and four departments participated in a three-week, intense design course in 2016: 43 from a German technical university, including 32 from the Chemistry Department (technical chemistry) and 11 from the Mechanical and Process Engineering Department; 14 from a private German university of applied sciences Chemical Engineering Department; and 12 from an American university Chemical Engineering Department. Students were divided into 12 interdisciplinary, intercultural teams, each consisting of 5-6 students. At most German technical universities, chemical engineering topics are typically divided into process engineering, taught in mechanical and process engineering departments, and kinetics and reaction engineering, taught in chemistry departments in their technical chemistry institutes. At the German universities of applied sciences, chemical engineering is more similar to the American university programs.

For this 2016 ADP course, student teams designed a $185 \mathrm{kt} / \mathrm{yr}$ capacity low density polyethylene (LDPE) plant. The industrial partner provided key data for this structured design project, which was broken into major tasks, e.g., mass balance, kinetics, heat balance, separation, safety, and economics. At the end of project, students presented their results to their peers, tutors, professors, and the industrial partner and then had the opportunity to visit and tour the plant they designed.

\section{Definition of competence}

Two main areas of competence were studied in the ADP course, team and design competences. Team competence was defined as having the knowledge, skills, and ability to solve complex problems and to produce excellent solution(s) within the structure of the team. This concept was further developed to include defining team and task, team climate, communication, and reflection (for a detailed description, please see Table 1$)^{23-26}$. 
Design competence focused on finding and evaluating variants and recognizing and solving complex design problems. These were further defined as having the ability to discover and design multiple solutions to a given problem and to effectively evaluate those solutions to determine the best solution, and having the ability to see the overall picture of a complex design problem, then breaking it into smaller, more manageable parts to solve while keeping the overall problem in view. The overall design process competence included problem scoping, developing solutions, and project realization (for a detailed description, please see Table 2) 27-30 $^{\text {. }}$

\section{Methods of assessment and analysis}

Team competences were adapted from the Comprehensive Assessment of Team Member Effectiveness (CATME) assessment ${ }^{31}$, which self-assesses students' ability to: contribute to a group project, communicate well within the group, resolve conflicts, and plan, schedule, and assess their group's progress. Design competence was self-evaluated by students to: measure their ability to find and evaluate different solutions to their problem(s); examine their use of criteria to evaluate their progress and design; assess their aptitude in carefully defining the overall problem(s) and sub-problem(s); determine their ability in developing alternative perspectives and solutions; and measure their use of networks and flow charts to keep track of design variables and the interrelationships.

These team and design competences were assessed three times during the ADP course with a mixture of closed-ended, Likert scale questions and open-ended questions. The first assessment on the first day of the course included questions concerning their intercultural and interdisciplinary awareness, motivation, expectation, and team competence as close-ended questions using a 1-5 Likert scale with 5 being strong and 1, weak. Students were also asked to explain what is design and teamwork as open questions as well as evaluate their knowledge level in design and teamwork on this 1-5 Likert scale. The second assessment, halfway through the course, self-assessed students' team (same questions as the first assessment) and design competence as closed-ended, 1-5 Likert scale questions. They were also asked to rate the quality of their solution and teamwork. The third assessment on the last day of the course included team and design competence, rating the quality of their overall solution and teamwork, level of knowledge in design and teamwork, whether they acquired design and teamwork skills, and open questions asking what they learned about teamwork and design. Competence in each area was averaged over the questions in each section to obtain an average competence for each time the assessment was administered and for an overall competence of the entire course.

The final ADP grades, based on individual and team efforts, working grade, presentation grade, and report grade, were also collected.

Qualitative analysis. The open questions asking students to describe the concepts of design and teamwork were analyzed for themes and word frequency using the software, NVivo (QSR International Pty Ltd, Victoria, Australia). The first pass through the written explanations yielded categories based on the students' own words. Categories representing the same theme were combined to avoid repetition, and were categorized according to the definition of design and teamwork previously described. Ones that did not fit with the pre-defined categories were placed in the other category. The analysis of the open question of what they had learned during the course included an additional category, Other-Learned, for responses that did not fit into the previously 
defined categories. Word clouds were generated to quickly determine over-arching themes and words in their explanations. Matrices were also generated showing how many times a category/theme appeared. Comparisons were made between the different teams and between the different departments as well as an overall analysis of all students.

Table 1: Rubric for quantitative score of teamwork open question.

\begin{tabular}{|c|c|c|c|c|}
\hline Excellent (5) & Proficient (4) & Basic (3) & Marginal (2) & Unacceptable (1) \\
\hline & $\begin{array}{l}\text { Minor deficiencies: } \\
\text { hit key } \\
\text { topics/categories but } \\
\text { not a clear } \\
\text { understanding of } \\
\text { details/points within } \\
\text { each }\end{array}$ & $\begin{array}{l}\text { Moderate } \\
\text { deficiencies: hit } \\
\text { some of the major } \\
\text { categories }\end{array}$ & $\begin{array}{l}\text { Major deficiencies: } \\
\text { hit a couple of } \\
\text { categories (briefly) } \\
\text { and unclear } \\
\text { descriptions }\end{array}$ & \\
\hline $\begin{array}{l}\text { Clear and complete } \\
\text { understanding and } \\
\text { explanation of } \\
\text { (below items): }\end{array}$ & $\begin{array}{l}\text { Overall sound } \\
\text { understanding and } \\
\text { explanation of : }\end{array}$ & $\begin{array}{l}\text { Some } \\
\text { understanding and } \\
\text { explanation of: }\end{array}$ & $\begin{array}{l}\text { Little grasp and } \\
\text { understanding and } \\
\text { explanation of: }\end{array}$ & $\begin{array}{l}\text { No explanation and } \\
\text { understanding of: }\end{array}$ \\
\hline \multicolumn{5}{|c|}{$\begin{array}{l}\text { Defining Team and Task: team goals, different roles needed in the group, division of work, and information } \\
\text { management (organization, storage, and sharing) }\end{array}$} \\
\hline \multicolumn{5}{|c|}{$\begin{array}{l}\text { Team Climate: including clear rules for working together, helping each other, recognizing and reacting to the } \\
\text { mood and feelings of team members }\end{array}$} \\
\hline \multicolumn{5}{|c|}{$\begin{array}{l}\text { Communication: with the group, outside parties (oral and written), conflict management (respect), constructive } \\
\text { feedback (criticism), creating a collective language }\end{array}$} \\
\hline \multicolumn{5}{|c|}{ Reflection: reflecting on work as group and by self, developing feedback } \\
\hline
\end{tabular}

Table 2: Rubric for quantitative score of design open question.

\begin{tabular}{|c|c|c|c|c|}
\hline Excellent (5) & Proficient (4) & Basic (3) & Marginal (2) & Unacceptable (1) \\
\hline $\begin{array}{l}\text { Discuss } \\
\text { interrelationships } \\
\text { between phases/parts } \\
\text { of the design process } \\
\text { and iterative nature of } \\
\text { design }\end{array}$ & $\begin{array}{l}\text { Minor deficiencies } \\
\text { in description and } \\
\text { understanding such } \\
\text { as use of some } \\
\text { criteria in } \\
\text { evaluation process } \\
\text { and to some degree } \\
\text { have alternative } \\
\text { designs }\end{array}$ & $\begin{array}{l}\text { Moderate } \\
\text { deficiencies such as } \\
\text { moderate } \\
\text { application of } \\
\text { software and } \\
\text { flawed alternatives }\end{array}$ & $\begin{array}{l}\text { Major deficiencies } \\
\text { in describing design } \\
\text { process such as one } \\
\text { design and no } \\
\text { evaluation }\end{array}$ & $\begin{array}{l}\text { Incapable of } \\
\text { describing design } \\
\text { process }\end{array}$ \\
\hline $\begin{array}{l}\text { Clear and complete } \\
\text { understanding and } \\
\text { explanation of (below } \\
\text { items): }\end{array}$ & $\begin{array}{l}\text { Overall sound } \\
\text { understanding and } \\
\text { explanation of: }\end{array}$ & $\begin{array}{l}\text { Some } \\
\text { understanding and } \\
\text { explanation of: }\end{array}$ & $\begin{array}{l}\text { Little grasp and } \\
\text { understanding and } \\
\text { explanation of: }\end{array}$ & $\begin{array}{l}\text { No explanation and } \\
\text { understanding of: }\end{array}$ \\
\hline \multicolumn{5}{|c|}{$\begin{array}{l}\text { Problem Scoping: Project goals and defining the problem, doing a customer needs assessment, and gather } \\
\text { information and research literature (good sources) }\end{array}$} \\
\hline \multicolumn{5}{|c|}{$\begin{array}{l}\text { Developing Solutions: Generate solutions (brainstorming), effective modeling the solution(s), use of software, } \\
\text { evaluating different solutions, define and use set of criteria for evaluation }\end{array}$} \\
\hline \multicolumn{5}{|c|}{$\begin{array}{l}\text { Project Realization: Use of evaluation and criteria to make decisions, communication within group and to } \\
\text { outside parties including written documentation, detailed modelling. }\end{array}$} \\
\hline
\end{tabular}

Quantitative analysis. A rubric was developed to score the open-ended questions and was scaled 1-5 to match the self-assessment Likert scales (Tables 1 and 2). This score was compared to the self-assessment of knowledge level in team and design skills, respectively. 
SPSS version 24 (SPSS IBM, New York, NY, USA) statistical software was used for all statistical measures. All means are shown as average \pm standard deviation unless noted otherwise.

\section{Results and Discussion}

Comparison of tradition and non-traditional design approach

The ADP course was compared to an accredited, traditional American chemical engineering (ChE) capstone design course (Table 3). Both courses strongly meet the ABET outcomes (c) ability to design a system, component, or process to meet desired needs; (d) the ability to work on multidisciplinary teams; (g) communicate effectively; and (k) ability to use the techniques, skills and modern engineering tools necessary for engineering practice. They more weakly emphasize (b) design and conduct experiments and analyze and interpret data. As can be seen from Table 3, the non-traditional ADP meets all the course outcomes of the traditional ChE capstone design course. In addition, the ADP course emphasizes the ABET criteria (f) understanding of professional and ethical responsibility and (h) the broad education necessary to understand the impact of engineering solutions in a global and societal context. The ADP course also has teams that are truly multidisciplinary, while most traditional American capstone design courses do not.

The format of the ADP course forces the teams to maximize their multidisciplinarity to achieve the overall project design in the limited time frame. It also further increases their communication skills by having to give daily team progress reports, communicate effectively with people from different cultures and disciplines and with peers, tutors, and professors, and they must communicate with industrial representatives, whose mother tongue is not English. From the technical standpoint of process design, the ADP course introduces the American ChE students to alternative software and process simulators outside of ASPEN for different parts of the project. This expands their skill set with process simulators that could do specific tasks better than ASPEN. The exposure to different perspectives and problem solving approaches of other cultures and disciplines teaches students that there are multiple solutions and solution pathways and hopefully in turn, to be more creative and innovative. This non-traditional approach to capstone design meets the requirements of a traditional capstone design but also offers a broader global and industrial perspective to process design.

\section{Assessment and analysis}

To establish a brief background and gain understanding of the students' motivation, expectations, and intercultural and interdisciplinary awareness, a short pre-assessment on the first day of the course was given. On average, students were aware that they use cultural specific knowledge when interacting with a person from another cultural, but there was a large variance between individual students (3.83 \pm 0.75$)$. Interestingly, students were less aware of differences in problem solving between cultures $(3.50 \pm 0.55)$ but slightly more aware between disciplines (3.67 \pm 0.52$)$. On average, students said they needed only slightly more knowledge and skills beyond content specific knowledge to be successful in this course $(3.50 \pm 0.55)$. From the motivation side, on average, students said this course was important to them but there was large variance from it being only a little important to being very important $(3.67 \pm 1.03)$. This course had students: from different disciplines and universities with different curricula; at different levels in their studies; and had students for which the course was required or an elective, which impacted motivation for taking this course and its importance to each student. For example, for the American ChE students, 
all were in their last or second to last semester before graduating with their bachelors, whereas the German students (both mechanical engineering and chemistry students) were in the first semester of their master's studies.

Table 3: Comparison of an ABET accredited, traditional American chemical engineering (ChE) capstone design class (non-shaded columns) to the non-traditional, immersive ADP course (shaded columns). a-k refers to the ABET student outcomes*. This table rates each outcome on a scale from 1-3, where 3 indicates a strong emphasis. 1-10 refers to the traditional ChE program course outcomes:

1) complete a Phase I process design package (BFD level);

2) complete a Phase II process design package (PFD level);

3) complete key elements of a Phase III process design package (P\&ID plus equipment specifications level);

4) use process simulators (Aspen Plus) for the synthesis and optimization of process designs;

5) estimate capital and manufacturing costs;

6) perform engineering economic and profitability analyses;

7) utilize experienced-base principles (heuristics) to confirm the suitability of process and associated equipment designs;

8) obtain required data for a design from literature;

9) work effectively as individuals and as a design group team member (second semester of design project); and 10) effectively communicate your design in both oral and written formats.

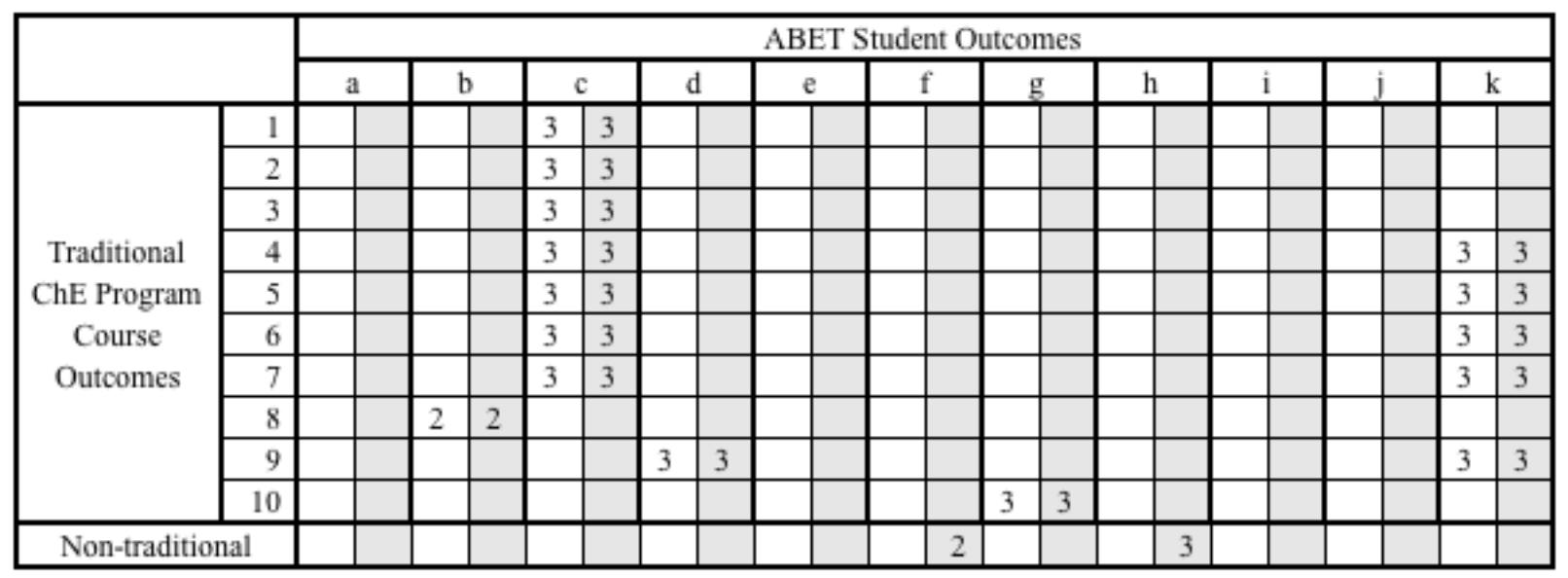

* (a) ability to apply mathematics, science and engineering principles; (b) ability to design and conduct experiments, analyze and interpret data; (c) ability to design a system, component, or process to meet desired needs; (d) ability to function on multidisciplinary teams; (e) ability to identify, formulate and solve engineering problems; ( $f$ ) understanding of professional and ethical responsibility; (g) ability to communicate effectively; (h) the broad education necessary to understand the impact of engineering solutions in a global and societal context; (i) recognition of the need for and an ability to engage in life-long learning; (j) knowledge of contemporary issues; and ( $k$ ) ability to use the techniques, skills and modern engineering tools necessary for engineering practice.

\section{Assessment of design and teamwork skills}

Student concepts of design and teamwork were scored against developed rubrics (Tables 1 and 2) and compared overall and across departments. Students assessed themselves on their overall design and teamwork skills over the course of the ADP project and whether they felt they further developed these skills from the project course.

Design. As can be seen in Figure 1, students overall scored low (1.56 \pm 0.66 , where 1 is the lowest possible score and 5 the highest) when graded against the developed rubric (Table 2), meaning their description of design was below marginal and slightly above unacceptable. They also rated their level and knowledge of design skills on the first day of the ADP course and again on the last 
day, and it was seen that they perceived a gain in design knowledge. A paired t-test was conducted to compare their pre and post knowledge. A significant increase was seen from the pre-assessment $(2.62 \pm 0.92)$ to post-assessment (3.19 \pm 0.80$)$; $\mathrm{t}(61)=-5.23, \mathrm{p}<0.0001$, Cohen's $\mathrm{d}=0.68$. There was also a significant increase in the quality of the solution, as assessed by the students, from midpoint of the course till the end (mid $=3.51 \pm 0.62$; post $=3.79 \pm 0.70 ; t(61)=-3.74, p<0.0001$, Cohen's $d=0.47)$. On average, students agreed that they acquired design skills from the ADP course (3.98 \pm 0.72$)$. Interestingly, the American ChE students ranked themselves as having more design knowledge than their German counterparts (Figure 1), perhaps because the Americans had just completed two semester-long design instructional courses the previous semester. There also may be a cultural difference between how Germans and Americans self-assess themselves. However, when examined within the grouped categories in Figure 1, the trends are clear.

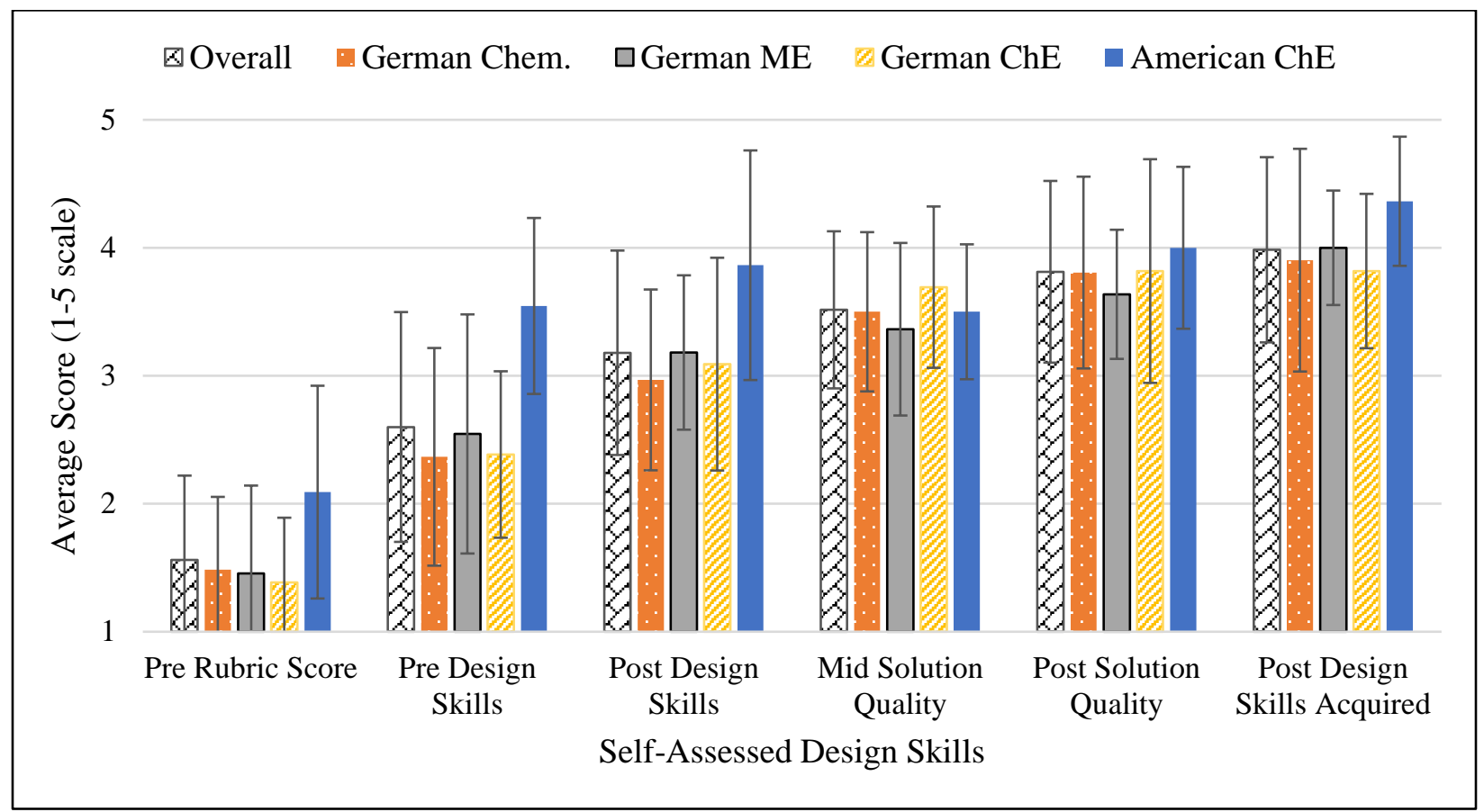

Figure 1: The self-assessment of design skills during the ADP course by university department, where overall includes all participating students. German Chem. is the technical German university chemistry department, German ME is the technical German university mechanical and process engineering department, German ChE is the German university of applied sciences chemical engineering department, and American $\mathrm{ChE}$ is the American university chemical engineering department. Pre indicates these were assessed on the first day of the course, mid, halfway through, and post, on the last day. Error bars represent standard deviation of the calculated average.

Teamwork. Students scored rather low in teamwork skills (2.44 \pm 0.58$)$ according to the developed rubric (Table 1) but higher in comparison to design skills. Their self-assessment (Figure 2) was better than marginal but still does not show that the students felt they had a basic understanding of teamwork skills. A paired t-test was calculated to compare students perceived knowledge level in teamwork skills on the first and last days of the ADP course. There was a significant difference between pre- $(3.49 \pm 0.77)$ and post- teamwork skills: $(3.79 \pm 0.76)$; $t(61)=-3.03, p=0.004$, Cohen's $d=0.39$. This indicates that students perceived that they did gain teamwork skills through the ADP course, but they did not think the quality of their teamwork increased from midway till 
end of the course (mid $=3.89 \pm 0.82$; post $=3.92 \pm 0.90$; $t(61)=-0.40, p=0.69$, Cohen's $d=0.05$ ). When asked if they acquired teamwork skills through the ADP course, on average, they said they did (3.66 \pm 0.93). Similar to design skills, the American ChE students ranked their knowledge level of teamwork skills slightly higher than their German counterparts, but when asked to rate the quality of their teamwork, they rated themselves slightly lower and similar to the German students. (Figure 2).

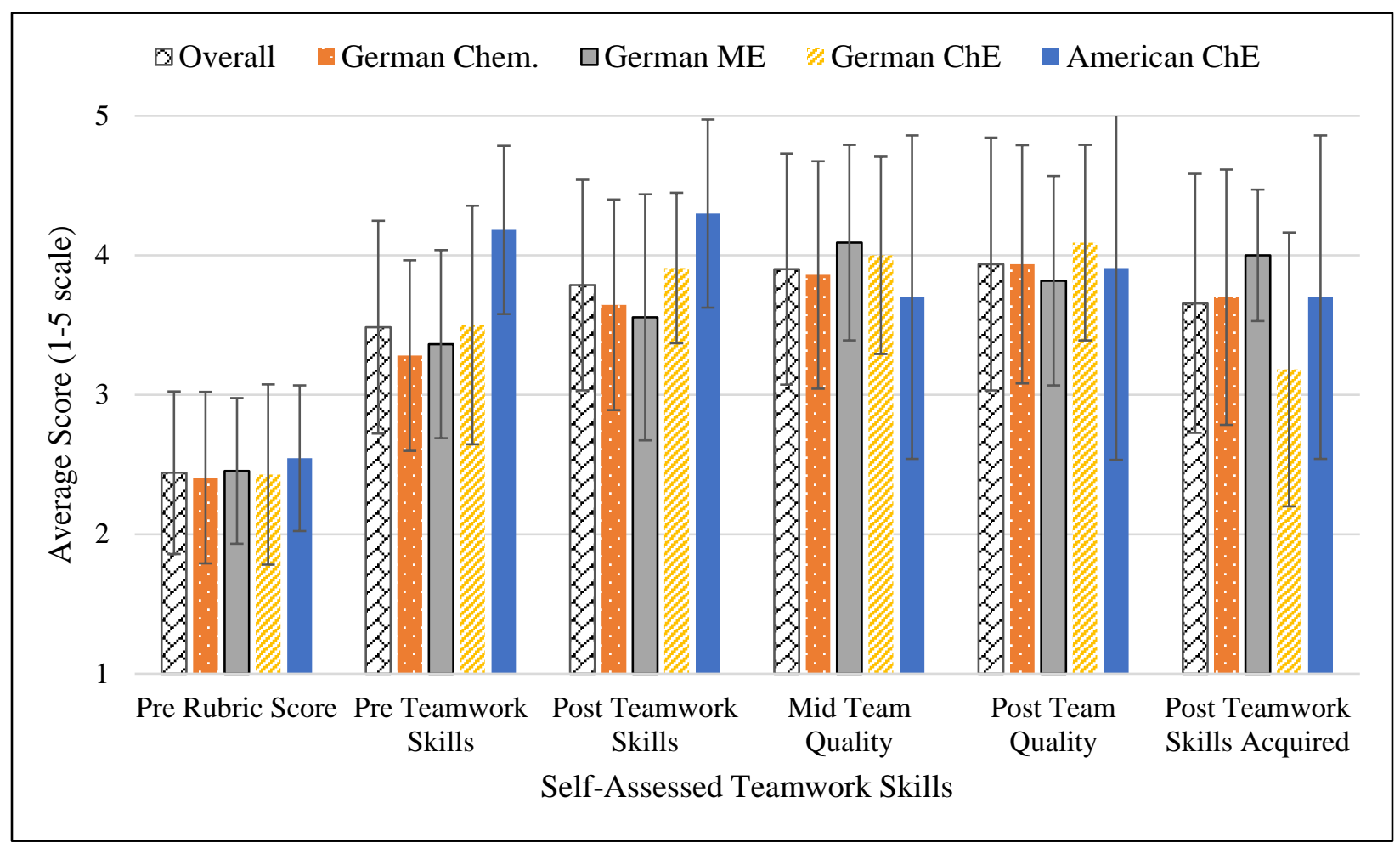

Figure 2: Self-assessment of teamwork skills during the ADP course by university department, where overall is all participating students. German Chem. is the technical German university chemistry department, German ME is the technical German university mechanical and process engineering department, German $\mathrm{ChE}$ is the German university of applied sciences chemical engineering department, and American $\mathrm{ChE}$ is the American university chemical engineering department. Pre indicates these were assessed on the first day of the course, mid, halfway through, and post, on the last day. Error bars represent standard deviation of the calculated average.

\section{Student Perceptions of Design and Teamwork}

Based on the lower rubric scores, an in-depth qualitative analysis was performed to explore students' understanding of design and teamwork. Student responses describing the concept of design and teamwork were combined, respectively, and analyzed using word clouds to see overarching themes. For the second, more detailed thematic analysis, all student responses were coded and organized into categories based on the above rubrics (Tables 1 and 2) with additional categories as needed, e.g., the category teamwork was added to the design concept. Percentage of total codes (meaning total segments coded) were calculated for each category and subcategory and compared. 
Design. The major themes that emerged from the word cloud analysis were knowledge and communication, and a more minor theme, team (work), also emerged from students' combined responses. Figure 3 shows a comparison of the major categories by university department for describing design from the second, more detailed thematic analysis. Briefly, more students commented on the need for teamwork (Team) along with a time schedule and structured work. The Other category also scored higher, mostly due to the coded segment of the need for existing, basic knowledge. The categories Developing Solutions and Project Realization scored lower overall. For example, in the category Developing Solutions, Team 2 emphasized developing actual solutions and evaluating those solutions, whereas Team 5 emphasized brainstorming new ideas and evaluating those. In the category, Project Realization, communication was most often identified as an important part of design, and in the category Problem Scoping, the highest subcategory was the need for process information. No team consistently mentioned all three of main categories, i, Developing Solutions, and Project Realization, in their description of design but mostly highlighted other attributes such as teamwork (Team) and having existing, basic knowledge (Other). When comparing the different university departments, the results were similar to the teams where teamwork and existing, basic knowledge were cited more often. The American ChE students scored lower in the Other category with a lower percentage of coded fragments citing knowledge as important in describing design. They also scored higher in Problem Scoping (process information and project goals) and Project Realization (communication along with adaptability and detailed studies) than the other departments. Students were asked to describe what they learned after the three-week course, and their answers were analyzed using the same category and subcategory system used for describing design on the first day. Most frequently cited were tools for design and teamwork. In the Team category, along with teamwork, the necessity of team roles was mentioned. Also, cited were (in a new category, Learned-Other) integrating perspectives, design as an iterative process (only one team, German mechanical engineers and chemists), integrating different perspectives, and simply how to solve problems.

The in-depth analysis reiterated the themes seen using word clouds but showed more details and understanding not seen the first time. From both analyses, the major themes for the concept of design were having existing, basic knowledge, communication (part of Project Realization and Team), and teamwork. Most teams did mention aspects of the three main parts of design: Developing Solutions, Problem Scoping, and Project Realization. They mostly reported on learning teamwork and different software tools for design, e.g., Predici, Aspen Plus, etc. 


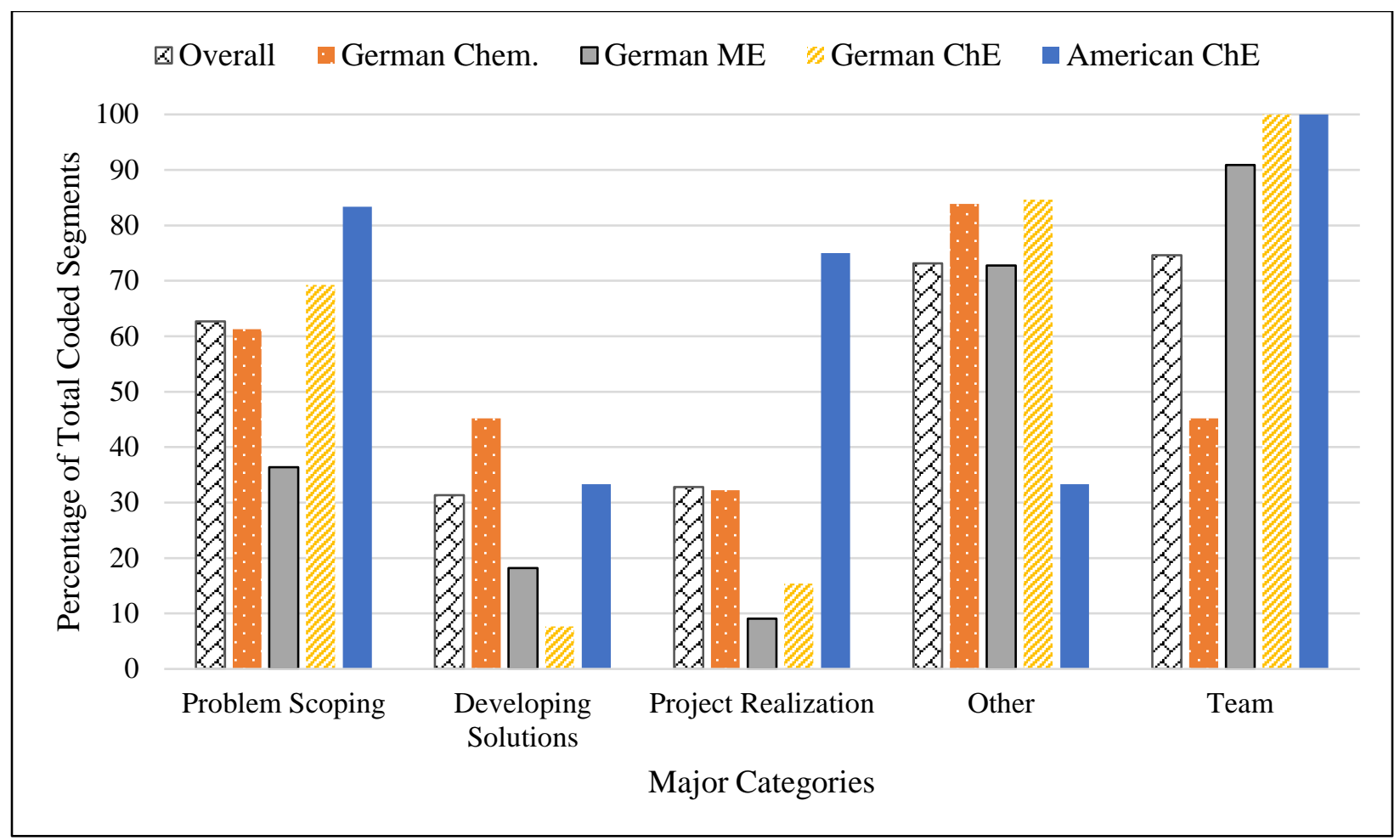

Figure 3: Coded segments of describing the concept of design by percentage of total coded segments of the major categories based on the rubrics (Table 2) by university department, where overall is all participating students, German Chem. is the technical German university chemistry department, German $\mathrm{ME}$ is the technical German university mechanical and process engineering department, German ChE is the German university of applied sciences chemical engineering department, and American ChE is the American university chemical engineering department.

Teamwork. The major themes that emerged from the simple, word cloud analysis of the student responses on the concept of teamwork were communication, team (work), respect, and knowledge. Figure 4 shows the major categories referenced by students' description of teamwork by university department from the second, more detailed thematic analysis. Communication was cited overall most often, which also included the subcategory of conflict resolution. In Defining Team and Task, division of work and goal-orientated work were mentioned, and in the category of Team Climate, cooperation and set-up rules were cited as being more important. All teams described the concept of teamwork similarly with communication as the most important aspect. When the responses were broken down by university department, similar results were found. The American ChE students mentioned evaluation and reflection as also important in teamwork. Student responses to what they had learned about teamwork were coded the same as their description of teamwork on the first day. The most cited coded segment was Communication including conflict resolution followed by Defining Team and Task, including division of work and team roles. In the breakdown by university department the major emphasis was on Communication. The American ChE students emphasized Defining Team and Task less than the other departments but also mentioned managing diversity, participation of all team members, and time management as being learned. 


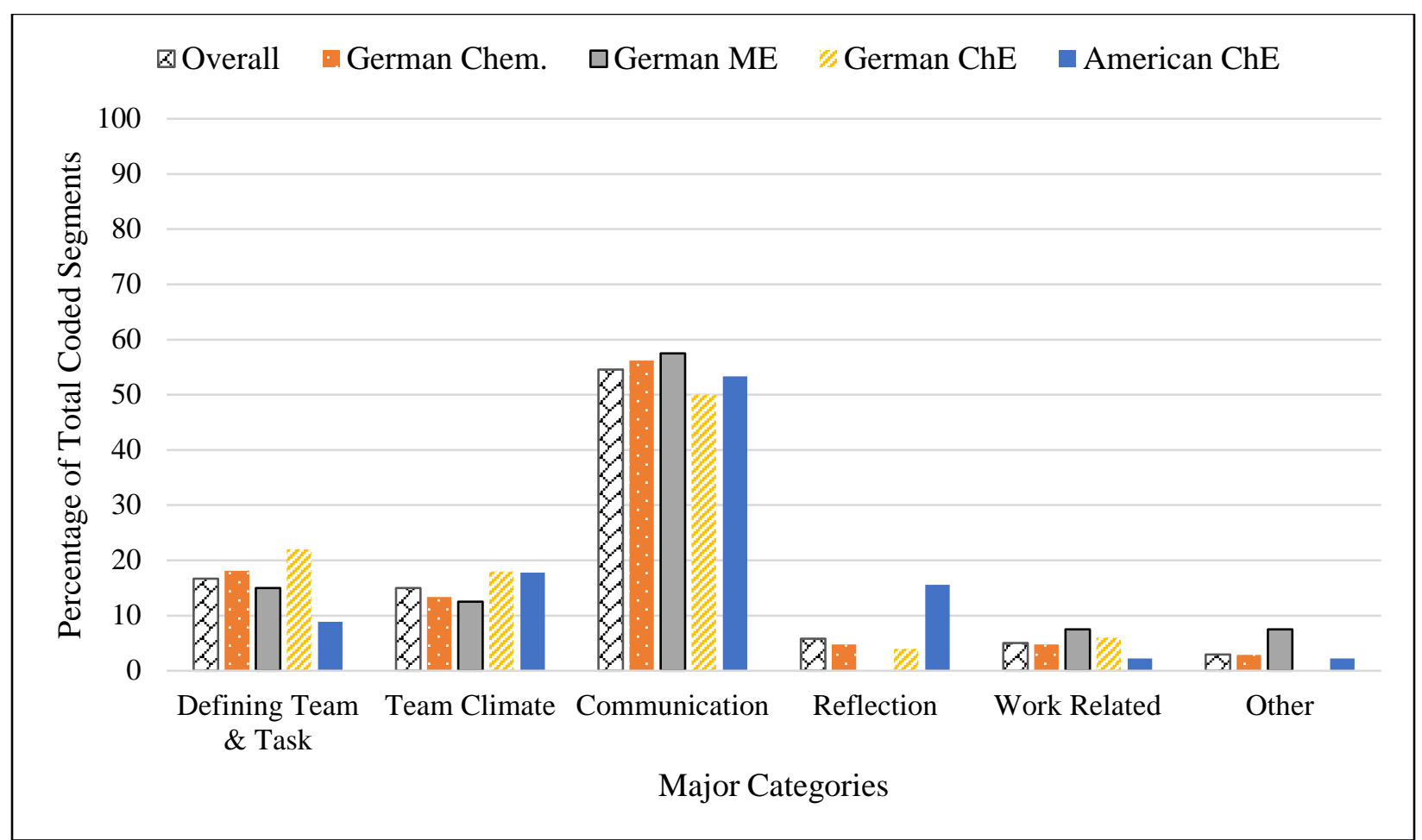

Figure 4: Coded segments of describing the concept of teamwork by percentage of total coded segments of the major categories based on the rubrics (Table 1) by university department, where overall is all participating students, German Chem. is the technical German university chemistry department, German $\mathrm{ME}$ is the technical German university mechanical and process engineering department, German ChE is the German university of applied sciences chemical engineering department, and American ChE is the American university chemical engineering department.

In summary, more students mentioned aspects of Defining Team and Task and Team Climate (categories from the rubric) as well as the major category of Communication, but fewer students mentioned Reflection. After the second, more detailed thematic analysis, work-related comments such as brainstorming/creativity, knowledge in their respective discipline, making decisions, time management, and work redundancy were only a small portion of the overall responses. The major themes from both analyses were communication (including conflict resolution) and different tasks (splitting the work load). Most teams reported on learning that communication, splitting the task(s) properly, and team roles are important in teamwork.

\section{Comparison of student perception and measured competence}

Students perceived themselves as having higher design and teamwork skills compared to their graded scores based on the rubrics, which showed students had below a basic understanding of both design and teamwork, but they had assessed themselves as having between a basic and proficient understanding. The in-depth, qualitative analysis showed that students mentioned different points of design and teamwork but none put the different parts together for a full, nuanced concept. It has been previously shown that students tend to over assess their own ability ${ }^{32}$, but other studies have shown correlations between self-assessments and course objective measurements ${ }^{33}$. In addition, students tend to have a difficulty separating engineering science from engineering design but rather see design as a set of defined problems within a larger problem ${ }^{34}$. 
Benefits and challenges of this approach

Through this intercultural, interdisciplinary capstone design course, students are exposed to alternative perspectives and problem solving approaches they normally would not have in a traditional capstone design course with only their ChE classmates. The intensive, immersive format of the ADP course allows students to focus completely on the project and have fewer distractions. This format contributes to the additional constraint of limited time, which leads to encouraging increased collaboration among team members and teams, especially for troubleshooting. This can lead to resource interdependence when each team member has a specific expertise and contribution from all members is needed to complete a project. And it has the additional impact of increasing their teamwork skills ${ }^{18}$. The time-constraint can increase selfmotivation, especially for troubleshooting model software. More diverse teams tend to outperform high ability solvers ${ }^{35}$, and multidisciplinary teams tend to have better final design projects in comparison to monodisciplinary teams ${ }^{20}$.

Challenges of this approach include potentially lower creativity in a more structured design, which arises from the time constraint of the intensive, immersive approach and keeping self-motivation and moral high from the intensity of the course. Through this course, it is difficult to easily determine an increase in design skills since they are not explicitly taught those skills but are implicitly through application. This challenge is similar to a traditional capstone design course.

\section{Conclusion and Outlook}

Passow (2012) surveyed recent engineering graduates in industry and determined the most important ABET criteria for professional success were problem solving, communication, ethics, design, teamwork, life-long learning, and engineering tools ${ }^{36}$. This non-traditional, intensive, intercultural, interdisciplinary capstone design course has been shown to meet and exceed these requirements and prepare ChE graduates with the skills and knowledge needed to succeed in their professional futures.

To meet the challenge of assessing design skills from the ADP course, scenario analysis with a simplified rubric will be explored and developed. The scenario analysis will look at the more detailed learning objectives of the ADP course and ask students more specifically to analyze a chemical processing plant situation and teamwork in this situation to make it less abstract for the students. Along with more course specific questions, the assessment will measure intercultural and interdisciplinary awareness, motivation, and expectations before and after the course to obtain a better view if students are also gaining in intercultural and interdisciplinary awareness and to assess their overall level of moral. 


\section{References}

1. Warnick, G. M. (2011). Global competence: Its importance for engineers working in a global environment. In: Proceedings from the $118^{\text {th }}$ Annual ASEE Conference and Exposition in Vancouver, BC, Canada.

2. Robinson, M.A.; Sparrow, P.R.; Clegg, C.; Birdi, K. (2005). Design engineering competencies: Future requirements and predicted changes in the forthcoming decade. In: Design Studies, 25:123-153.

3. Turley, R.T.; Bieman, J.M. (1995). Competencies of exceptional and non-exceptional software engineers. In: Journal of Systems and Software, 28(1):19-38.

4. Peschges, K.-J.; Reindel, E. (1998). Project-oriented engineering education to improve key Competencies. In: Global Journal of Engineering Education, 2(2):181-186.

5. ABET. (2016). Criteria for accrediting engineering programs, 2016-2017. http://www.abet.org/accrediation/accreditation-criteria/criteria-for-accrediting-engineering-programs-20162017/. Accessed December 29, 2016.

6. Bairaktarova, D.; Pilotte, M. K.; McNeill, N. (2014). Challenging students' view and assumptions through project-based learning. In: Proceedings from the 121st Annual ASEE Conference and Exposition in Indianapolis, IN.

7. Felder, R.; Brent, R. (2003). Designing and teaching courses to satisfy the ABET engineering criteria. In: The Journal of Engineering Education, 92(1):7-25.

8. Jonassen, D.; Strobel, J.; Lee, C. B. (2006). Everyday problem solving in engineering: Lessons for engineering educators. In: Journal of Engineering Education, 95(2):131-151.

9. Mills, J. E.; Treagust, D. (2003). Engineering education - is problem-based or project-based learning the answer? In: Australian Journal of Engineering Education, online publication.

10. Hoit M.; Ohland M. (1998). The impact of a discipline-based introduction to engineering course on improving retention. In: Journal of Engineering Education, 87(1):79-85.

11. Knight, D. W.; Carlson, L. E.; Sullivan, J. F. (2003). Staying in Engineering: Impact of a hands-on, teambased, first-year projects course on student retention. In: Proceedings of the 2003 ASEE Annual Conference and Exposition, Nashville, TN.

12. Knight, D. W.; Carlson, L. E.; Sullivan, J. E. (2007). Improving engineering student retention through handson, team based, first-year design projects. In: $31^{\text {st }}$ International Conference on Research in Engineering Education, Honolulu, HI.

13. Marra, R. M.; Palmer, B.; Litzinger, T. A. (2000). The effects of a first-year engineering design course on student intellectual development as measured by the perry scheme. In: Journal of Engineering Education, 89(1): 39-45.

14. Mahendran, M. (1995). Project-based civil engineering courses. In: Journal of Engineering Education, 84(1): 75-79.

15. Dym, C. L.; Agogino, A. M.; Eris, O.; Frey, D. D.; Leifer, L. J. (2005). Engineering design thinking, teaching, and learning. In: Journal of Engineering Education, 94(1):103-120.

16. Lehmann, M.; Christensen, P.; Du, X.; Thrane, M. (2008). Problem-oriented and project-based learning (POPBL) as an innovative learning strategy for sustainable development in engineering education. In: European Journal of Engineering Education, 33(3):283-295. 
17. Perkins, D. (2009). Making learning whole: How seven principles of teaching can transform education. San Francisco, CA: Jossey Bass.

18. Colbeck, C. L.; Campbell, S. E., Bjorklund, S. A. (2000). Grouping in the dark: what college students learn from group projects. In: The Journal of Higher Education, 71(1):60-83.

19. Goltz, S. M.; Hietapelto, A. B.; Reinsch, R. W.; Tyrell, S. K. (2008). Teaching teamwork and problem solving concurrently. In: Journal of Management Education, 32(5):541-562.

20. Miller, R. L; Olds, B. M. (1994). A model curriculum for a capstone course in multidisciplinary engineering design. In: Journal of Engineering Education, 83(4):311-316.

21. Davies, W.M. (2006). Intensive teaching formats: A review. In: Issues in Educational Research, 16(1):120.

22. Hall, M. V.; Wilson, L. A.; Sanger, M. J. (2012). Student success in intensive versus traditional introductory college chemistry courses. In: Journal of Chemical Education, 89:1109-1113.

23. Duarte, D. L.; Snyder, N. T. (1999). Managing virtual teams.

24. Matsui, T.; Kakuyama, T.; Onglatco, M.U. (1987). Effects of goals and feedback on performance in groups. In: Journal of Applied Psychology, 72(3):407-415.

25. Smolek, J; Hoffman, D.; Moran, L. (1999). Organizing teams for success. In: Supporting work team effectiveness, 24:62.

26. Wegge, J. (2000). Participation in group goal setting: Some novel findings and a comprehensive model as a new ending to an old story. In: Applied Psychology, 49(3):498-516.

27. Anders, B., Pinkelman, R. J., Hampe, M. J., Kelava, A.: Development, assessment, and comparison of social, technical, and general (professional) competencies in a university engineering advanced design project - A case study. In: Musekamp, F., Spöttl, G. (eds.): (2015). Kompetenz im Studium und in der Arbeitswelt. Nationale und internationale Ansätze zur Erfassung von Ingenieurkompetenzen. Competence in Higher Education and the Working Environment. National and International Approaches for Assessing Engineering Competence. Frankfurt am Main, Bern, Bruxelles, New York, Oxford, Warszawa, Wien: Peter Lang (Vocational Education and Training: Research and Practice).

28. Atman, C. J.; Bursic, K. M. (1998). Verbal protocol analysis as a method to document engineering student design processes. In: Journal of Engineering Education 87(2):121-132.

29. Atman, C. J.; Cardella, M. E.; Turns, J.; Adams, R. (2005). Comparing freshmen and senior engineering design processes: An in-depth follow-up study. In: Design Studies, 26:325-357.

30. Atman, C. J.; Adams, R. S.; Cardella, M. E.; Turns, J.; Mosburg, S.; Saleem, J. (2007). Engineering design processes: A comparison of students and expert practitioners. In: Journal of Engineering Education, 96(4):359-379.

31. Loughry, M.L.; Ohland, M.W.; Moore, D.D (2207). Development of a theory-based assessment of team member effectiveness. In: Educational and Psychological measurement, 67:505.

32. Furmanski, J.; Kane, S. R.; Gupta, S.; Pruitt, L. A. (2006). Work in progress: Problem-based learning and assessment of competence in an engineering biomaterials course. In: Proceedings from the ASEE/IEE Frontiers in Education Conference, San Diego, CA. 
33. Mehta, S.I.; Schlecht, N. W. (1998). Computerized assessment technique for large classes. In: Journal of Engineering Education, 87(2):167-172.

34. Downey, G.; Lucena, J. (2003). When students resist: Ethnography of a senior design experience in engineering education. In: International Journal of Engineering Education, 19(1):168-176.

35. Hong, L.; Page, S. E. (2000). Groups of diverse problem solvers can outperform groups of high-ability problem solvers. In: Proceedings of the National Academy of Sciences, 101(46):16385-16389.

36. Passow, H. J. (2012). Which ABET competencies do engineering graduates find most important in their work. In: Journal of Engineering Education, 101(1):96-118. 